\title{
O QUE É COGNITIVISMO: Fundamentos filosóficos
}

\author{
Cognitive Science: Fbilosophical fundamentals
}

Castañon, Gustavo (2007). O que é cognitivismo: Fundamentos filosóficos. São Paulo: EPU.

\author{
Elizabeth Carvalho da Veiga
}

Doutora em Psicologia pela Universidade Complutense de Madri. Professora do Curso de Psicologia da Pontifícia Universidade Católica do Paraná (PUCPR), Curitiba, PR - Brasil, e-mail: bethveiga@hotmail.com

Este livro traz uma contribuição inovadora para o cenário da psicologia e da filosofia brasileira: a reflexão sobre os fundamentos teóricos do cognitivismo. Esse movimento, nascido por um lado de uma rejeição ao behaviorismo, que já na metade do século passado demonstrava sinais de cansaço e, por outro, de uma recusa da psicanálise, que tendia a se tornar uma escolástica, reafirmou a prioridade da consciência como ponto de partida da investigação psicológica. Finalmente se retomava na psicologia aquilo que seriam seus temas óbvios: a mente e a consciência, por contraposição ao comportamento e o inconsciente, que por tantos anos dominaram o horizonte dos psicólogos. Mas para isso foi preciso que ocorresse uma revolução científica, fora dos domínios da própria psicologia. Uma revolução que teve como ponto de partida o desenvolvimento da cibernética, do computador, da teoria da informação e da neurociência, que se apresentavam agora como as ferramentas que permitiriam, progressivamente, abrirmos a caixa-preta abandonada pela psicologia por décadas.

Esta obra nos introduz e nos familiariza com os principais filósofos que refletiram sobre as bases do cognitivismo. Traz uma novidade na interpretação histórica da revolução cognitiva, esta é apresentada como conseqüência e não como causadora do surgimento de uma visão pós-moderna de ciência, iniciada por filósofos posteriores ao positivismo lógico, uma visão do conhecimento sem a qual o cognitivismo não teria se tornado possível e suas premissas jamais seriam aceitas pela comunidade científica. O autor caminha num primeiro momento nas Ciências Cognitivas indo dos antecedentes psicológicos do cognitivismo, passando pela psicologia cognitiva e o contexto de seu surgimento. Traz os avanços científicos que propiciaram a psicologia cognitiva e aborda a ciência cognitiva de hoje. $\mathrm{Na}$ 
segunda parte, nos brinda com a Psicologia e a Ontologia, onde retrata os pressupostos ontológicos da psicologia cognitiva, o objeto da psicologia cognitiva, a imagem do ser humano no cognitivismo e a psicologia e o problema mente-corpo. A terceira etapa do livro refere-se à Psicologia Cognitiva e à Epistemologia, abordando os pressupostos epistemológicos da psicologia cognitiva, cognitivismo e racionalismo crítico, a explicação psicológica no cognitivismo e a circularidade da investigação científica cognitiva. Na quarta etapa, o autor se detém em 5 questões: a natureza integrativa da pesquisa em psicologia cognitiva; o processo geral de pesquisa científica da psicologia cognitiva; métodos descritivos e psicologia cognitiva; métodos construtivos e psicologia cognitiva e métodos experimentais e psicologia cognitiva.

O autor, nesta obra, propõe-se a investigar quais são os pressupostos ontológicos, antropológicos, epistemológicos e metodológicos que são a base do projeto cognitivista de Psicologia Moderna. 